\title{
Lung Cancer with Eosinophilia in the Peripheral Blood and the Pleural Fluid
}

\author{
Sachiko Matsumoto, Tomonori Tamai, Kohsuke Yanagisawa, Shinichi Kawamura and Shigeru Fujita
}

\begin{abstract}
A case of lung cancer associated with eosinophilia in the peripheral blood and pleural fluid is reported. A 55-year-old man with a tumor in the right lower lung lobe and right pleural effusion was admitted to Ehime University Hospital. Histology of specimens biopsied under a bronchoscope revealed that he had poorly differentiated squamous cell carcinoma. On admission, his peripheral blood leukocyte count was $11,500 / \mu l$ with $7.8 \%$ eosinophils and the pleural fluid showed a high eosinophil count (60.5\%). After chemotherapy, blood eosinophilia disappeared and the pleural effusion was decreased with the reduction of the tumor. The patient's serum had the activity to stimulate eosinophil proliferation in human bone marrow cell culture, suggesting that the tumor may have produced an eosinophil proliferating factor.

(Internal Medicine 31: 525-529, 1992)
\end{abstract}

Key words: eosinophil proliferating factor, eosinophilic pleural effusion

\section{Introduction}

Among the patients with malignant tumor not associated with parasitic infestations, allergic diseases or certain skin diseases, some patients have eosinophilia. Numerous explanations have been proposed for this phenomenon. Tumor necrosis and extensive dissemination are reported to induce eosinophilia (1-3). In a few cases with lung cancer, eosinophil chemotactic factor has been demonstrated in tumor extracts $(4,5)$. Recent studies have suggested the existence of a tumor which produces an eosinophil proliferating factor or an eosinophil colony stimulating factor which in turn stimulates eosinophil colony formation (6-9).

Here we report a patient with lung cancer, in whom eosinophil count was increased in the peripheral blood and the pleural fluid, and stimulation of eosinophil proliferation by the patients's serum was observed in human bone marrow cell culture.

\section{Case Report}

A 55-year-old man was admitted to our hospital on January 30, 1986, because of cough, sputum and right chest pain. The patient had smoked 20 cigarettes a day for 30 years and had no allergic or skin disease in the past.
On admission, crepitant rale was heard in the right lower lung field, and percussion was dull at the same site. The chest X-ray revealed a nodular shadow at the right lower lung lobe and pleural effusion on the right side (Fig. 1A). Exfoliative cytology of the sputum showed no malignant cells. Histological examination of specimens biopsied under a bronchoscope revealed had poorly differentiated squamous cell carcinoma (Fig. 2).

The peripheral blood leukocyte count was $11,500 / \mu \mathrm{l}$, of which $7.8 \%$ were mature eosinophils (Table 1 ). Bone marrow aspiration revealed hypocellularity with $52.4 \%$ granulocytes, $12 \%$ erythroblasts and $13.2 \%$ eosinophils (2.2\% immature type and $11.0 \%$ mature type) without abnormal cells.

Sodium and chloride levels in the blood were found to be slightly low by electrolyte analysis. Serum enzymes, blood urea nitrogen and creatinine were within the normal range. Immunoglobulin $E$ level and the tumor marker CEA were not elevated. Ova and parasites were negative in his stool. The pleural fluid was bloody and positive for Rivalta reaction. Cytological examination revealed no malignant cells, and differential leukocyte counts were $60.5 \%$ eosinophils, $5.0 \%$ lymphocytes, and $34.5 \%$ others (Fig. 3). Image diagnosis including abdominal echograph and CT scan showed no evidence of metastasis to the liver, pancreas or kidneys.

From the First Department of Internal Medicine, School of Medicine, Ehime University, Ehime

Received for publication October 20, 1990; Accepted for publication December 9, 1991

Reprint requests should be addressed to Dr. Sachiko Matsumoto, the First Department of Internal Medicine, School of Medicine, Ehime University, Shigenobu, Onsen-gun, Ehime 791-02, Japan 


\section{Matsumoto et al}

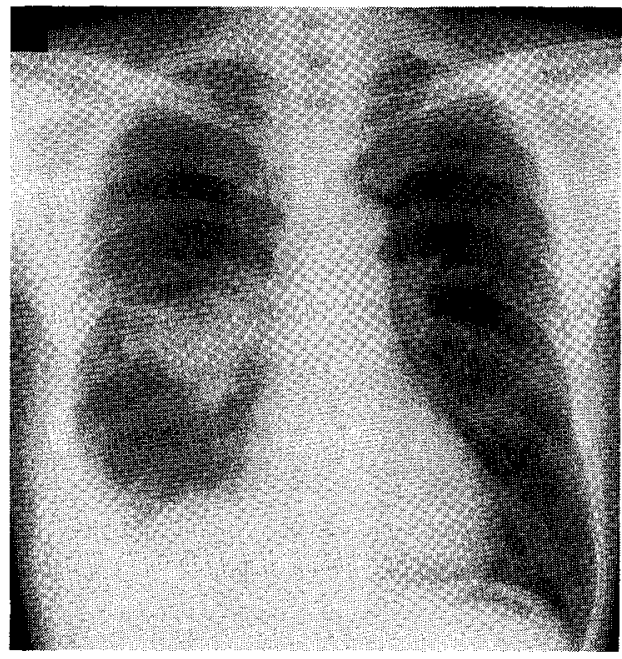

A



B

Fig. 1. A) Chest $X$-ray on admission. A nodular shadow can be seen in the right lung $S_{6}$ region and pleural effusion on the right side. B) Chest X-ray after chemotheraphy. There is shrinking of the tumor shadow and a decrease in the pleural fluid.



Fig. 2. Microscopic findings of the tumor cells (hematoxylineosin stain, $\times 400$ ).

Figure 4 shows the clinical course of the patient. After diagnosed as lung cancer (stage 1 by the international stage system), chemotherapy consisting of cisplatin (100 mg/body), vindesine ( $3 \mathrm{mg} /$ body) and mitomycin-C ( $10 \mathrm{mg} /$ body) without any steroid was administered, because he refused to have an operation. After two weeks the tumor shadow on the X-ray distinctly shrank and pleural effusion reduced (Fig. 1B). After the drug administration was started, both the peripheral leukocyte count and the ratio of eosinophils decreased. On March 7 , the leukocyte count was $5,900 / \mu \mathrm{l}$ and the ratio of eosinophils was $3.0 \%$ indicating the return to a normal hematological picture. The patient refused the consecutive treatment in our hospital; he then went to a clinic in his neighborhood. Therefore, we could not observe his course thereafter.
The effect of patient's serum and pleural fluid on eosinophils in human bone marrow cell culture.

Non-adherent cells of human bone marrow taken from a healthy male volunteer were used as target cells, and the culture was performed by the liquid suspension method. To non-adherent bone marrow cells $\left(5.0 \times 10^{5}\right.$ cells $\left./ \mathrm{ml}\right)$ in Iscove's modified Dulbecco's medium (IMDM) containing $20 \%$ fetal calf serum (FCS), either the patient's serum, the patient's pleural fluid or healthy human serum was added at $10 \%$ the final concentration, and cultures were performed under humidified air with $5 \% \mathrm{CO}_{2}$ at $37^{\circ} \mathrm{C}$. After 14 days, the cell population in the culture was analyzed on May-Grunwald-Giemsa stained preparation. As shown in Table 2, the eosinophil number was markedly increased when the patient's serum was used $\left(95.7 \times 10^{3} \mathrm{cells} / \mathrm{ml}\right.$ compared to $5.0 \times 10^{3} \mathrm{cells} / \mathrm{ml}$ at the start of culture), whereas the increase in eosinophils was much less when the patient's pleural fluid or healthy human serum was used $\left(9.8 \times 10^{3}\right.$ cells $/ \mathrm{ml}$, patient's pleural fluid; $25.4 \times 10^{3}$ cells $/ \mathrm{ml}$, healthy human serum). The result showed that the patient's serum had activity to stimulate eosinophil proliferation.

\section{Discussion}

The increased blood eosinophil level in the present case was not associated with any disorders other than lung cancer, which may cause it; the level decreased concomitant with reduction of the tumor. In a human bone marrow cell culture, stimulation of eosinophil proliferation by the patient's serum was observed. However, isolation and characterization of eosinophil proliferating factor were not successful in this case.

The incidence of eosinophilia associated with malignant 


\section{Lung Cancer with Eosinophilia}

Table 1. Laboratory Findings

\begin{tabular}{|c|c|c|c|c|c|}
\hline ESR & $75 \mathrm{~mm} / \mathrm{h}$ & $\begin{array}{l}\text { Mo } \\
\text { Ly }\end{array}$ & $\begin{array}{r}5.6 \% \\
16.6 \%\end{array}$ & AFP & $2.9 \mathrm{ng} / \mathrm{ml}$ \\
\hline Urinalysis & normal & $\begin{array}{l}\text { Ly } \\
\text { Plasma }\end{array}$ & $\begin{array}{r}10.0 \% \\
0.4 \%\end{array}$ & Immunoglobulin & \\
\hline & & $\mathrm{Ebl}$ & $12.0 \%$ & $\operatorname{IgE}$ & $256 \mathrm{U} / \mathrm{ml}$ \\
\hline Stool study & & $\mathrm{M} / \mathrm{E}$ ratio & 5.33 & & \\
\hline occult blood & $(-)$ & & & Sputum culture & \\
\hline parasites and ova & $(-)$ & Blood chemistries & & $\alpha$-Streptococcus & $(+)$ \\
\hline & & $\mathrm{Na}$ & $136 \mathrm{meq} / \mathrm{l}$ & Neisseria & $(+)$ \\
\hline Peripheral blood & & $\mathrm{K}$ & $5.0 \mathrm{meq} / \mathrm{l}$ & Candida albicans & $( \pm)$ \\
\hline $\mathrm{RBC}$ & $391 \times 10^{4} / \mu 1$ & $\mathrm{Cl}$ & $98 \mathrm{meq} / \mathrm{l}$ & & \\
\hline $\mathrm{Hb}$ & $12.6 \mathrm{~g} / \mathrm{dl}$ & GOT & $9 \mathrm{IU} / \mathrm{I}$ & Sputum cytology & \\
\hline $\mathrm{Ht}$ & $36.8 \%$ & GPT & $16 \mathrm{IU} / \mathrm{l}$ & cancer cells & $(-)$ \\
\hline WBC & $11,500 / \mu \mathrm{l}$ & $\mathrm{LDH}$ & $66 \mathrm{IU} / \mathrm{l}$ & & \\
\hline Neutro & $61.1 \%$ & AlP & $128 \mathrm{IU} / 1$ & Pleural fluid findings & \\
\hline Eo & $7.8 \%$ & $\gamma$-GTP & $9 \mathrm{IU} / \mathrm{I}$ & bloody & \\
\hline $\mathrm{Ba}$ & $1.7 \%$ & LAP & $35 \mathrm{IU} / 1$ & Rivalta reaction & $(+)$ \\
\hline Mo & $7.4 \%$ & T.protein & $6.7 \mathrm{~g} / \mathrm{dl}$ & CEA & $2.4 \mathrm{ng} / \mathrm{ml}$ \\
\hline Ly & $22.0 \%$ & Alb. & $50.5 \%$ & bacteria, fungi & $(-)$ \\
\hline Platelet & $53.4 \times 10^{4} / \mu 1$ & $\alpha 1-\mathrm{gl}$ & $5.5 \%$ & cytology & \\
\hline & & $\alpha 2-\mathrm{gl}$ & $17.9 \%$ & Neutro & $11.5 \%$ \\
\hline Bone marrow & & $\beta-\mathrm{gl}$ & $10.2 \%$ & Eo & $60.5 \%$ \\
\hline $\mathrm{NCC}$ & $5.1 \times 10^{4} / \mu 1$ & $\gamma-\mathrm{gl}$ & $15.9 \%$ & $\overline{\mathrm{Ba}}$ & $1.0 \%$ \\
\hline $\mathrm{Mgk}$ & $30 / \mu \mathrm{I}$ & BUN & $16 \mathrm{mg} / \mathrm{dl}$ & Mo & $22.0 \%$ \\
\hline $\mathrm{Mbl}$ & $1.0 \%$ & Creatinine & $0.9 \mathrm{mg} / \mathrm{dl}$ & Ly & $5.0 \%$ \\
\hline Pro & $2.4 \%$ & Uric acid & $4.3 \mathrm{mg} / \mathrm{dl}$ & cancer cells & $(-)$ \\
\hline My & $7.6 \%$ & & & & \\
\hline Met & $1.4 \%$ & Serology & & ECG & normal \\
\hline St & $17.4 \%$ & VDRL & $(-)$ & & \\
\hline Seg & $21.4 \%$ & TPHA & $(-)$ & \multirow{3}{*}{\multicolumn{2}{|c|}{$\begin{array}{l}\text { Abdominal CT, ultrasonography } \\
\text { no evidence of metastasis }\end{array}$}} \\
\hline Eo & $13.2 \%$ & CRP & $3+$ & & \\
\hline $\mathrm{Ba}$ & $0.6 \%$ & CEA & $2.4 \mathrm{ng} / \mathrm{ml}$ & & \\
\hline
\end{tabular}

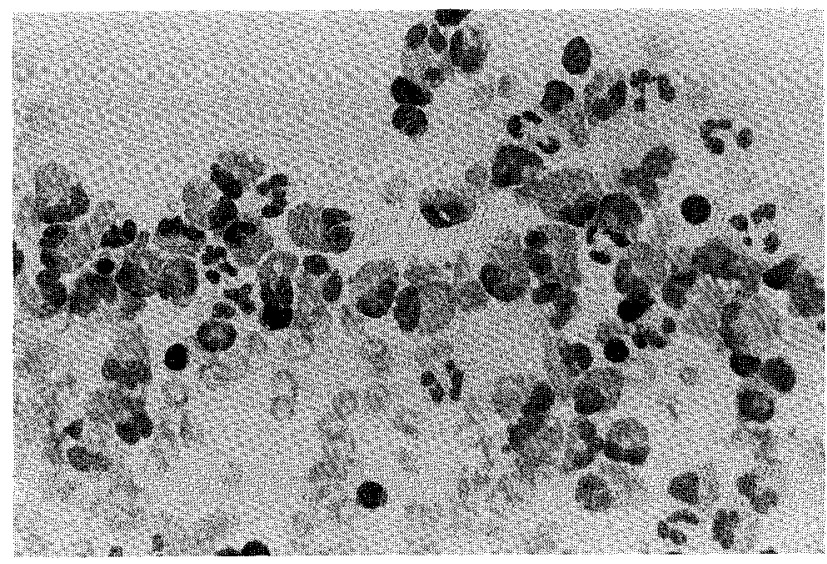

Fig. 3. May-Giemsa stain of the pleural fluid. Many eosinophils can be seen $(\times 400)$.

tumor has been reported to be $26.3 \%$ by Grewe and Schlitter (10), and $11.6 \%$ by Linke (11). Among the Japanese population, the ratio was reported as $0.8 \%$ by Asano and Ohsawa (12) and $4 \%$ by Kajiwara (13). Isaacson and Rapoport (1) reported that malignant tumor accompanying eosinophilia generally occurs in the digestive system (stomach, colon, pancreas) with prominent metastasis and poor prognosis.

Various causes of tumor-associated eosinophilia have been postulated. Some reports state that tumor necrosis $(1,2)$, extensive dissemination $(1,3)$, vagal reflexes $(14)$, or local stimulation of connective tissue around the tumor (15) induce eosinophilia. Wassermann et al (4) extracted peptide which is preferentially chemotactic for eosinophils, from a large-cell anaplastic carcinoma of human lung; other similar studies have been reported $(5,16)$.

With regard to the production of eosinophil proliferating factor by the tumor, Slungaard et al in 1982 first reported a case of lung cancer (6). In 1984, Kodama et al demonstrated the presence of both eosinophil colony stimulating factor and eosinophil chemotactic factor in lung cancer tissues (8). Also, Kajiwara reported that an eosinophil proliferating factor exists in the cytosol of gastric cancer and colon cancer cells (13). In this case, the fact that proliferative stimulation of eosinophils by the patient's serum was observed in a human bone marrow cell culture suggested the possibility of the production of an eosinophil proliferating factor by the tumor itself. Slungaard et al reported a glycoprotein produced by a tumor with a molecular weight of 45,000 which directly acted on bone marrow and caused eosinophilia (6).

In recent years, participation of various hematopoietic growth factors including colony stimulating factors (CSFs) on the proliferation and differentiation of hematopoietic 


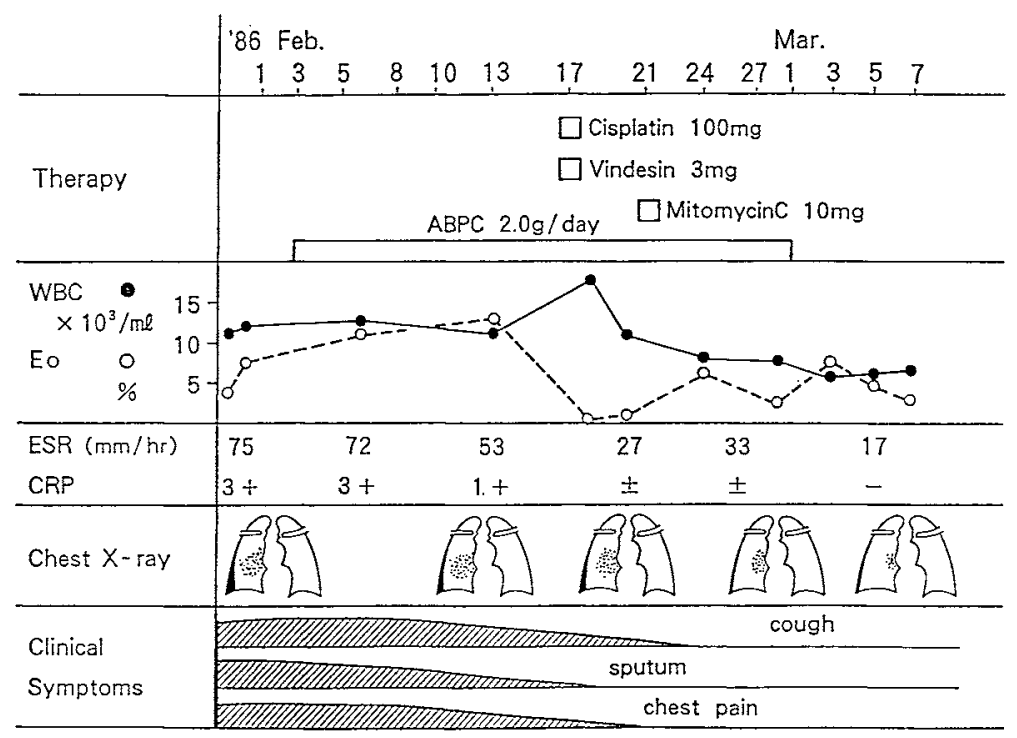

Fig. 4. Clinical course.

Table 2. Effect of Patient's Scrum and Pleural Fluid on Healthy Human Marrow Cells in Liquid Suspension Culture

\begin{tabular}{|c|c|c|c|c|c|}
\hline & $\begin{array}{l}\text { Prior to } \\
\text { culture }\end{array}$ & Medium & $\begin{array}{l}\text { Patient's } \\
\text { serum }\end{array}$ & $\begin{array}{c}\text { Patient's } \\
\text { pleural fluid }\end{array}$ & $\begin{array}{c}\text { Healthy human } \\
\text { serum }\end{array}$ \\
\hline $\begin{array}{l}\text { Cell count } \\
\text { Cell types }\end{array}$ & $5.0 \times 10^{5} / \mathrm{ml}$ & $3.0 \times 10^{5} / \mathrm{ml}$ & $3.3 \times 10^{5} / \mathrm{ml}$ & $3.9 \times 10^{5} / \mathrm{ml}$ & $3.9 \times 10^{5} / \mathrm{ml}$ \\
\hline \multicolumn{6}{|l|}{ Cell types } \\
\hline Mbl & $2.0 \%$ & $0.0 \%$ & $0.0 \%$ & $0.0 \%$ & $0.5 \%$ \\
\hline Neutro & $88.0 \%$ & $82.5 \%$ & $58.5 \%$ & $72.0 \%$ & $78.5 \%$ \\
\hline Eo & $\begin{array}{c}1.0 \% \\
\left(5.0 \times 10^{3} / \mathrm{ml}\right)\end{array}$ & $\begin{array}{c}3.0 \% \\
\left(9.0 \times 10^{3} / \mathrm{ml}\right)\end{array}$ & $\begin{array}{c}29.0 \% \\
\left(95.7 \times 10^{3} / \mathrm{ml}\right)\end{array}$ & $\begin{array}{c}2.5 \% \\
\left(9.8 \times 10^{3} / \mathrm{ml}\right)\end{array}$ & $\begin{array}{c}6.5 \% \\
\left(25.4 \times 10^{3} / \mathrm{ml}\right)\end{array}$ \\
\hline Mo & $2.5 \%$ & $2.0 \%$ & $5.5 \%$ & $6.0 \%$ & $6.0 \%$ \\
\hline Ly & $5.5 \%$ & $9.5 \%$ & $1.0 \%$ & $16.0 \%$ & $4.0 \%$ \\
\hline Plasma & $1.0 \%$ & $2.5 \%$ & $0.0 \%$ & $0.0 \%$ & $0.0 \%$ \\
\hline
\end{tabular}

Normal nonadherent bone marrow cells were incubated in media containing $20 \%$ FCS with $10 \%$ of supplement for 14 days. Absolute number of eosinophils is given in parentheses.

progenitor cells has become evident. Interleukin 3 (IL-3), interleukin 5 (IL-5) and granulocyte-macrophage CSF (GM-CSF) are known to act on colony-forming unit eosinophils (CFU-Eo). In human bone marrow cell culture, recombinant human IL-3 (17), murine IL-5 (18) and recombinant human GM-CSF (19) are reported to stimulate proliferation of the eosinophil colonies. In the present case, further cumulative studies are necessary to ascertain whether tumor-associated eosinophil proliferating factor is correlated to IL-3, IL-5 or GM-CSF.

In the present case, a large increase of eosinophils in the pleural fluid was observed, but no obvious sign of proliferative stimulation on eosinophils was found in the pleural fluid. The pathological condition with a great number of eosinophils in pleural fluid has been termed eosinophilic pleural effusion (EPE). It has been reported that EPE occurs concomitant with various background diseases, but malignant tumors are rarely involved
(20-23). The causes for EPE have not yet been clearly defined, however many speculations have been proposed: intrusion of air or erythrocytes into thoracic cavity, heterogeneous protein or its decomposition product, eosinophilic chemotactic factors including immumecomplex and specific lymphokines (24-26). Since the ratio of eosinophils in the pleural fluid was higher than that in the peripheral blood in this case, it was considered that the eosinophils were mobilized from the peripheral blood to thoracic cavity. There is a possibility of the presence of tumor-associated eosinophil chemotactic factor in this case.

The significance of eosinophilia associated with malignant tumor and the mechanism of increase of eosinophils in thoracic cavity are not yet clarified; further studies on this mechanism will be necessary.

Acknowledgments: The authors would like to thank Professor Yuzuru Kobayashi for his help in reviewing of this paper. 


\section{Lung Cancer with Eosinophilia}

\section{References}

1) Isaacson $\mathrm{NH}$, Rapoport $\mathrm{P}$. Eosinophilia in malignant tumors: Its significance. Ann Intern Med 25: 893, 1946.

2) Murray RC. The use of the absolute eosinophil count in the diagnosis of neoplasm. N Engl J Med 248: 848, 1953.

3) Viola MV, Chung EDB, Mukhopadhyay MG. Eosinophilia and metastatic carcinoma. Med Ann DC 41: 1, 1972.

4) Wassermann SI, Goetzl EJ, Ellman, L, et al. Tumor-associated eosinophilotactic factor. N Engl J Med 290: 420, 1974.

5) Goetzl EJ, Tashjian AH, Austen KF. Production of a low molecular weight eosinophil polymorphonuclear leukocyte chemotactic factor by anaplastic squamous cell carcinoma of human lung. $\mathrm{J}$ Clin Invest 61: 770, 1978.

6) Slungaard A, Vercellotti G, Zanjani E, et al. Tumor-induced eosinophilia and endocardial fibrosis, evidence for ectopic eosinophilopoietin production and $\mathrm{O}_{2}$-radical-mediated endothelial damage. Trans Assoc Am Physicians 95: 8, 1982.

7) Slungaard A, Ascensao J, Zanjani E, et al. Pulmonary carcinoma with eosinophilia. N Engl J Med 309: 778, 1983.

8) Kodama T, Takeda K, Kameya $T$, et al. Large cell carcinoma of the lung associated with marked eosinophilia. Cancer 54: 2313,1984 .

9) Hirata J, Koga T, Nishimura J, et al. Pancreatic carcinoma associated with marked eosinophilia. A case report. Eur J Haematol 39: 462, 1987.

10) Grewe HE, Schlitter HE. Die plaktische Bedeutung der Bluteosinophilie die malignene Tumoren. Med Klin 50: 1965, 1955 (in German).

11) Linke H. Neutrophile, eosinophile und erythroleukamishe Blutoreaktionen der Carzinomen. Schweiz Med Wochenshr 85: 950, 1955 (in German).

12) Asano S, Ohsawa N. Human malignant tumors producing hematopoietic factors. Nippon Naika Gakkai Zasshi 71: 1665, 1982 (in Japanese).

13) Kajiwara T. Eosinophilia in the patients with carcinoma of the stomach and colon, release of eosinophilopoietic factor from carcinoma tissue. Arch Jpn Chir 55(2): 306, 1986 (in Japanese).

14) Strisower R. Beitrag zur kasuistic hochgradiger Bluteosinophilic bei eiser Karzinomatose und einem Lymphogranulomatose. Klin Wochenschr 26: 16, 1913 (in German).

15) Paviot J, Levrat M, Guichard A. L'eosinophilie sanguine des tumeurs malignes. Ann Anat Pathol 12: 113, 1935 (in Fiench).

16) Iwasaki $K$, Torisu $M$, Fujimura $T$. Malignant tumor and eosinophils. Cancer 58: 1321, 1986.

17) Bot FJ, Dorssers I, Wagemaker G, et al. Stimulating spectrum of human recombinant multi-CSF (IL-3) on human marrow precursors: Importance of accessory cells. Blood 71: 1609, 1988.

18) Clutterbuck EJ, Sanderson CJ. Human eosinophil hematopoiesis studied in vitro by means of murine eosinophil differentiation factor (IL5): Production of functionally active cosinophils from normal human bone marrow. Blood 71: 646, 1988.

19) Tomonaga M, Golde DW, Gasson JC. Biosynthetic (recombinant) human granulocyte-macrophage colony-stimulating factor: Effect on normal bone marrow and leukemia cell lines. Blood 67: 31, 1986

20) Campbell GD, Webb WR. Eosinophilic pleural effusion: A review with the presentation of seven new cases. Am Rev Respir Dis 90: 194, 1964.

21) Veress JF, Koss LG, Schrieber K. Eosinophilic pleural cffusion. Acta Cytol (Baltimore) 23: 40, 1979.

22) Adelman M, Albelda SM, Gottlieb J, et al. Diagnostic utility of pleural fluid eosinophilia. Am J Med 77: 915, 1984.

23) Wysenbeek AJ, Lahav M, Aelion JA, et al. Eosinophilic pleural effusion. A review of 36 cases. Respiration 48: 73, 1985.

24) Bower G. Eosinophilic pleural effusion: A condition with multiple cases. Am Rev Respir Dis 95: 746, 1967.

25) Cohen S, Ward PA. In vitro and in vivo activity of a lymphocyte and immune complex-dependent chemotactic factor for eosinophils. J Exp Med 133: 133, 1971.

26) Laster CE, Gleich GJ. Chemotaxis of eosinophils and neutrophils by aggregated immunoglobulins. J Allergy Clin Immunol 48: $297,1971$. 